\title{
Peculiarities Of Triazoloazepinium Bromides Effect On Steel Microbial
}

Corrosion

\author{
Iryna M. Kurmakova ${ }^{a^{*}}$, Olena S. Bondar ${ }^{a}$, Viktoria I. Vorobyova ${ }^{\mathrm{b}}$, Margarita I. Skiba $^{\mathrm{c}}$, \\ Elena E. Chygyrynets ${ }^{\mathrm{b}}$, Natalia R. Demchenko ${ }^{\mathrm{d}}$ \\ ${ }^{a}$ Department of Chemistry, T.H. Shevchenko National University «Chernihiv Colehium», Hetmana \\ Polubotka Street, 53, Chernihiv 14013, Ukraine \\ ${ }^{\mathrm{b}}$ Department of Physical Chemistry, National Technical University of Ukraine "Igor Sikorsky Kyiv \\ Polytechnic Institute”, Peremohy Ave, 37, Kyiv, 03056,Ukraine \\ ${ }^{c}$ Department of Technology of inorganic compounds and ecology, Ukrainian State University of \\ Chemical Technology, Gagarin Avenue 8, Dnipro, 49005, Ukraine \\ ${ }^{\mathrm{d}}$ Department of Biology, T.H. Shevchenko National University «Chernihiv Colehium», Hetmana
}

Polubotka Street, 53, Chernihiv 14013, Ukraine i.kurmakova@gmail.com

Keywords: biocorrosion, triazoloazepinium bromides, inhibitor, carbon steel.

Triazoloazepinium bromides act as biocides against sulfate-reducing bacteria and can produce an effect on mild steel microbial corrosion. It has been established that under the competing adsorption, the compounds with the properties of corrosion inhibitors can form a film, which protects the steel surface, before it is settled by corrosively active microorganisms. The protective film ensures the inhibition efficiency of up to $98.7 \%$. With triazoloazepinium bromides of the 2 nd group, corrosively active microorganisms colonize the steel surface before the inhibitor creates the protective layer. In this case, the biocorrosion accelerates by up to 6.25 times. Different effect of triazoloazepinium bromides on steel biocorrosion rate is explained by the molecular structure.

\section{Introduction}

Microbiologically influenced corrosion (MIC) is a phenomenon, which deals with the enhancement or acceleration of corrosion reaction by microorganisms. Microbial corrosion is one of the main types of corrosion, damaging oil and gas industry equipment, equipment for processing sulfide ore, heat and power equipment, sewage treatment equipment and other. Through MIC attacks, metallic materials, among which steel could be identified as a basic material of construction, in industrial installations lose mechanical properties including ductility, structural strength and eventually structural integrity of the industrial installation of their application. For averting MIC induced failures, millions of dollars are expended annually in many countries, and this 
cost ranged increasingly into billions of dollars when other related crises are accounted for. This makes search for corrosion control practices necessary for attaining safety and environmentally-friendly industrial processes.

MIC can occur under anaerobic and aerobic conditions. Among the composites of natural microbe communities, sulfate-reducing bacteria (SRB) act most aggressively in anaerobic conditions. According to the type of energy processes, sulfate-reducing bacteria are divided into two groups. First group of bacteria can oxidize organic substances to acids and carbon dioxide. Second group of bacteria can oxidize organic substances completely to carbon dioxide. Representatives of the first group are the vibrioins of the genus Desulfovibrio, spore sticks (genus Desulfotomaculum), and spikeless rods. To the second group of sulfate-reducing bacteria belongs the only representative Desulfotomaculum acetooxidans.

As a result of their vital activity, sulfatereducing bacteria restore sulfate ions to sulfide ions. These bacteria actively absorb hydrogen, which release during the cathodic process. The presence of sulphides and hydrogen sulphide in the corrosive environment markedly accelerates corrosion [1]. The development of corrosion contributes to the presence in the corrosive environment of ferrous ions.

If these ions are sufficient to bind the whole of the liberated hydrogen sulphide, then on the metal surface formed a loose plaque of iron sulphide, facilitating the progress of the reaction cathodic depolarization. Corrosion has a pitting character, corrosion products are black.

Biocidal inhibitors can serve as an effective means of corrosion inhibition, as biological factor is considered to be the main factor of microbial corrosion [2]. In the course of inhibition of the bacterial corrosion of metals by compounds with biocidic action, we observe the following competing processes: the adsorption of particles of the inhibitor on the metal surface leading to the formation of protective films and changes in the structure of the double electric layer and in the kinetics of electrochemical reactions; the adsorption of particles of the inhibitor on the surfaces of bacterial cells, which is the first stage of interaction of the inhibitor (biocide) with microorganisms; the chemotaxis of bacteria; and the formation of biofilms on the metal surface in which the microorganisms become more resistant to the action of the biocide.

Substances which are biocidal, particularly against SRB, have been found among the compounds of pyrazole, thiazole, benzimidazole, quinone [3-8], including suggested by us inhibitors-biocides - derivatives of imidoazepinium [9], N-isopropylacetanilide [10], triazoloazepinium acetonitrile [11], pyridine [12].

Triazoloazepinium bromides have demonstrated high biocidal activity against SRB and their satellites $[13,14]$, which makes these 
compounds promising for the anticorrosion protection. Certain compounds of the studied range have shown high effectiveness under the inhibition of mild steel microbial corrosion [15]. The effect of triazoloazepinium bromides on steel biocorrosion requires a more thorough investigation.

The objective of this paper is to study the peculiarities of the effect, produced by triazoloazepinium bromides with biocidal properties against SRB, on the mild steel biocorrosion and define its mechanism of action.

\section{Experimental part}

\section{Material and methods}

Triazoloazepinium bromides have been studied (Table 1), the synthesis method of which is presented in [16].

Model medium Postgate "B" [17] with and without culture of SRB was used as a testing corrosive medium. Postgate "B" medium composition per liter: $\mathrm{KH}_{2} \mathrm{PO}_{4}-0.5 \mathrm{~g}$; $\mathrm{NH}_{4} \mathrm{Cl}-$ $1.0 \mathrm{~g} ; \mathrm{CaSO}_{4} \times 2 \mathrm{H}_{2} \mathrm{O}-1.0 \mathrm{~g} ; \mathrm{MgSO}_{4}-2.0 \mathrm{~g}$; calcium lactate $-3.5 \mathrm{~g}$; yeast extract $(5 \%)-10$ $\mathrm{ml} ; \mathrm{FeSO}_{4} \times 7 \mathrm{H}_{2} \mathrm{O}(5 \%$ solution in $1 \% \mathrm{HCl})-10$ $\mathrm{ml}$; ascorbic acid (5\%) - $2 \mathrm{ml} ; \mathrm{NaHCO}_{3}(5 \%)-$ in quantity for $\mathrm{pH}$ 7.5. The acidity was measured with $\mathrm{pH}$-meter/ionomer pH/ION $340 \mathrm{i}$.

SRB culture was strain Desulfovibrio sp. M.4.1 [18]. Subculture concentration was $10 \%$ of the medium volume, number of bacteria in the subculture was $10^{9}$ cell $/ \mathrm{ml}$.
Table 1. Studied triazoloazepinium bromides

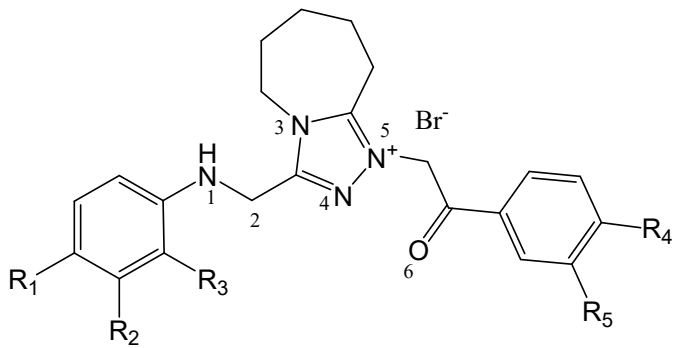

\begin{tabular}{|c|c|c|c|c|c|}
\hline Compound & $\mathrm{R}_{1}$ & $\mathrm{R}_{2}$ & $\mathrm{R}_{3}$ & $\mathrm{R}_{4}$ & $\mathrm{R}_{5}$ \\
\hline $\mathbf{I}$ & $-\mathrm{CH}_{3}$ & $-\mathrm{H}$ & $-\mathrm{H}$ & $-\mathrm{H}$ & $-\mathrm{H}$ \\
\hline $\mathbf{I I}$ & $-\mathrm{OCH}_{3}$ & $-\mathrm{H}$ & $-\mathrm{H}$ & $-\mathrm{Cl}$ & $-\mathrm{H}$ \\
\hline $\mathbf{I I I}$ & $-\mathrm{OCH}_{3}$ & $-\mathrm{H}$ & $-\mathrm{H}$ & $-\mathrm{Br}$ & $-\mathrm{H}$ \\
\hline $\mathbf{I V}$ & $-\mathrm{H}$ & $-\mathrm{Cl}$ & $-\mathrm{CH}_{3}$ & $-\mathrm{H}$ & $-\mathrm{H}$ \\
\hline $\mathbf{V}$ & $-\mathrm{CH}_{3}$ & $-\mathrm{H}$ & $-\mathrm{H}$ & $-\mathrm{Cl}$ & $-\mathrm{H}$ \\
\hline $\mathbf{V I}$ & $-\mathrm{Cl}$ & $-\mathrm{H}$ & $-\mathrm{H}$ & $-\mathrm{Cl}$ & $-\mathrm{H}$ \\
\hline $\mathbf{V I I}$ & $-\mathrm{Cl}$ & $-\mathrm{Cl}$ & $-\mathrm{H}$ & $-\mathrm{CH}$ & $-\mathrm{H}$ \\
\hline $\mathbf{V I I I}$ & $-\mathrm{H}$ & $-\mathrm{H}$ & $-\mathrm{H}$ & $-\mathrm{Cl}$ & $-\mathrm{H}$ \\
\hline $\mathbf{I X}$ & $-\mathrm{H}$ & $-\mathrm{Cl}$ & $-\mathrm{CH}$ & $-\mathrm{Br}$ & $-\mathrm{H}$ \\
\hline $\mathbf{X}$ & $-\mathrm{Cl}$ & $-\mathrm{Cl}$ & $-\mathrm{H}$ & $-\mathrm{Cl}$ & $-\mathrm{Cl}$ \\
\hline
\end{tabular}

\section{Gravimetric measurements}

The corrosion tests were performed with the help of gravimetric method [19]. The mild steel St3ps coupons (surface area $0.002 \mathrm{~m}^{2}$ ), polished to the 4-5 class of accuracy, were used for the gravimetric testing. Before being placed in the corrosive medium, the steel coupons were cleaned with acetone, and weighed with analytical scales accurate to $5 \cdot 10^{-5} \mathrm{~g}$. Coupons exposure time was 7; 75 and 180 days under $300 \mathrm{~K}$. Inhibitor concentration was $0.1 ; 0.25 ; 0.5$ and $1 \mathrm{~g} / 1$.

Corrosion rate with or without the inhibitors was calculated with the help of the formula: 


$$
\mathrm{k}_{\mathrm{m}}=\Delta \mathrm{m} /(\mathrm{S} \cdot \tau)
$$

where $\Delta \mathrm{m}$ - weight loss in $\mathrm{g}$; $\mathrm{S}$ - area in $\mathrm{m}^{2}$; $\tau$ - exposure time in hours.

Corrosion inhibition coefficient was calculated with the help of the formula:

$$
\gamma_{\mathrm{m}}=\mathrm{k}_{\mathrm{m}} / \mathrm{k}_{\mathrm{m}}^{\prime}
$$

where, $\mathrm{k}_{\mathrm{m}}, \mathrm{k}_{\mathrm{m}}$ is the corrosion rate without and with the inhibitor.

The inhibition efficiency (IE) was calculated using the following equation:

$$
\mathrm{IE}=\left(1-1 / \gamma_{\mathrm{m}}\right) \cdot 100 \%
$$

Statistical analysis of the experimental data (the corrosion rate) for the reliability level 95\% was conducted with the help of Microsoft Excel. The experiment was conducted three times.

\section{Electrochemical measurements}

Electrochemical tests [17] were performed with the help of potentiostat ПИ-50-1.1 and programmer PR-8. In this test a cylindrical steel electrode made of St3ps steel, which had been molded into Teflon casing, was used. The preparation of the electrode surface to the testing included polishing, washing with distilled water and with the studied solution. Three-electrode cell with the separated cathode and anode scope was used. Polarization curves were measured from the potential of free corrosion to $-0.85 \mathrm{~V}$ and from $-0.85 \mathrm{~V}$ to $0 \mathrm{~V}$. Potentiodynamic polarization studies were carried out in the potential range of $\pm 200 \mathrm{mV}$ with respect to open circuit potential (OCP) at a scan rate of $1 \mathrm{mV} / \mathrm{sec}$.
Chloride silver electrode $(\mathrm{E}=0.22 \mathrm{~V})$ was used as a comparison electrode, which was conducted to the steel electrode with the help of electrolytic bridge and Lugin capillary. The extra electrode was a platinum one. The electrode potentials, provided in the paper, were recalculated in accordance with the common hydrogen electrode. The results are presented as data curves of the correlation between the voltage $(\mathrm{E}, \mathrm{V})$ and current density logarithm (lgi, $\left(\mathrm{i}, \mathrm{A} / \mathrm{sm}^{2}\right)$ ).

\section{Microbiology measurements}

The number of the SRB, inoculated to the correspondent liquid selective medium Postgate "B", was calculated using the Most Probable Number method.

Compounds biocidal activity against the culture of SRB was studied with the help of the agar diffusion test. Sterile filter-paper disks, impregnated with the $2 \%$ alcohol solution of triazoloazepinium bromides, were used.

The concentration of biogenic hydrogen sulfide was measured with iodometric titration.

\section{Scanning electron microscope (SEM)}

The surface analysis of the biofilm, formed on metal samples surface, was performed with scanning electron microscope (SEM). To fix the grown biofilm to the steel surface, the coupons were immersed for $1 \mathrm{~h}$ in a 2\% glutaraldehyde solution, dehydrated with 4 ethanol solutions (15 min each) of volume \%, $25 \%, 50 \%, 75 \%$ and $100 \%$ successively, air dried overnight [20]. After fixation, the coupons 
were examined, using field emission scanning electron microscopy FEIE-SEM XL 30. With the help of electron microscope the picture was taken in the mode of functioning in secondary electrons. Maximum residual pressure in the microscope pillar was no more than $6.7 \cdot 10^{-4} \mathrm{~Pa}$ under the gun current of $76 \mathrm{~mA}$.

\section{Energy dispersive spectroscopy (EDS)}

Energy dispersive spectrum (EDS) was used to analyze the elemental composition of corrosion products (S-3000N, HITACHI, Japan). Before EDS (X-max 50, Japan) analysis of the biofilms and corrosion products, the coupons were pretreated by being soaked in a phosphate buffer solution containing 2.5\% (w/w) glutaraldehyde for $8 \mathrm{~h}$ in order to immobilize the biofilms to the coupon surface. Afterwards, all the coupons were dried with a nitrogen gas stream and placed in desiccators. The composition of corrosion products on the coupon was analyzed by X-ray diffraction (XRD). XRD patterns were recorded by a diffractometer between 10 and $90^{\circ} \mathrm{C}-2 \theta$ with $\mathrm{Cu} \mathrm{K} \alpha$ radiation at a rating of $40 \mathrm{kV}, 20 \mathrm{~mA}$.

\section{Quantum chemical calculations}

The calculations of the molecule atoms electric charge were done using the computer software Hyperchem 7.0. (Hypercube, Inc.). The geometry optimization was obtained by application of the conjugate gradient method Fletcher-Reeves with PM3 parameterization. Considering the salts dissociation in the water- salt medium, effective charges were calculated for triazoloazepinium cations.

Quantum chemical calculations has been found to be successful in providing insight into chemical reactivity and selectivity in terms of global molecular properties, such as electronegativity $(\chi)$ and chemical potential $(\mu)$ [21]. According to Koopman's theorem, the frontier orbital energies $\mathrm{E}_{\mathrm{HO} O}$ and $\mathrm{E}_{\mathrm{LUMO}}$ are related to the ionization potential, I, and the electron affinity, A, of iron and the inhibitor molecule by the following relations: A $=-$ ELumo, $\mathrm{I}=-\mathrm{E}_{\text {Hомо }}$ [22].

$$
\chi=-\mu=1 / 2(\mathrm{I}+\mathrm{A})
$$

The hardness $\eta$ of an electronic system is defined as [23]:

$$
\eta=1 / 2(\mathrm{I}-\mathrm{A})
$$

where I and A are the ionization potential and electron affinity [22].

The global softness (S), is the inverse of global hardness and is given as [23]:

$$
\mathrm{S}=1 / 2 \eta
$$

The global electrophilicity index $(\omega)$ was introduced by Parr et al. is given by:

$$
\omega=\frac{(\mathrm{I}+\mathrm{A})^{2}}{8(\mathrm{I}+\mathrm{A})}
$$

In considering the adsorption process from the point of view of the acid-basic interaction, the important quantitative parameters characterizing this process are the degree of charge transfer, that is, the interaction strength of acid-acceptor molecules (iron surface) and the donor base (investigated 
substances) and the magnitude of the energy change that accompanies the formation of the complex. The associated energy change $\Delta \mathrm{E}$ from base $\mathrm{B}$ to acid $\mathrm{A}$, is given as:

$$
\Delta \mathrm{E}=\frac{\left(\mu_{\mathrm{B}}-\mu_{\mathrm{A}}\right)^{2}}{2\left(\eta_{\mathrm{A}}-\eta_{\mathrm{B}}\right)}
$$

$\chi=-\mu-$ electronegativity, $\mathrm{eV}$;

$\eta$ - chemical hardness, eV;

A, B - indices in formulas $(4,5)$;

A - characteristics of the molecule of the test substance;

B - characteristics of the elemental lattice of the surface of iron.

The electronegativity of metal surface is replaced by the work function for Fe surface, theoretically equals $4.82 \mathrm{eV}$ and the hardness metal which equals $0 \mathrm{eV}$ for bulk metals [22, 23].

\section{Results and discussion}

\section{Microbiology measurements}

Biocidal activity of triazoloazepinium bromides against the SRB is demonstrated in fig.1. The diameter of bacteria growth inhibition zone under the $2 \%$ substance concentration is 35 $65 \mathrm{~mm}$, which indicates high biocidal activity. It is characteristic for all the studied compounds and shows almost no dependence on the structure of the molecules, particularly the nature of the substitutes in benzol fragments.

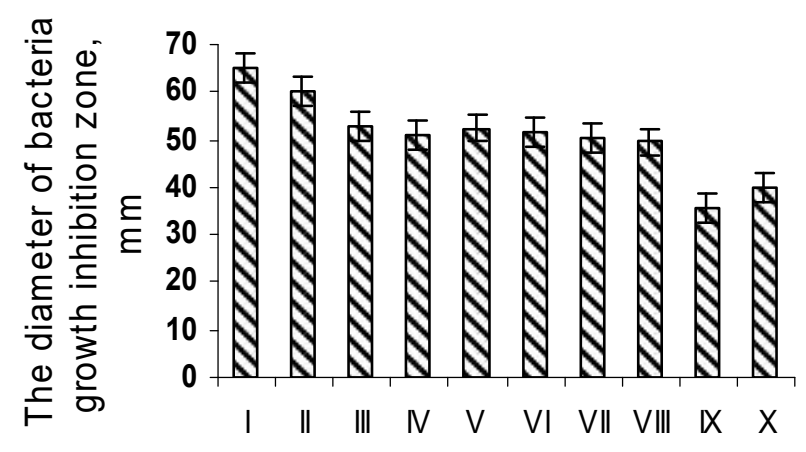

Figure 1. Biocidal activity of triazoloazepinium bromides against the sulfate-reducing bacteria.

\section{Gravimetric measurements}

The gravimetric testing results of triazoloazepinium bromides effect on steel St3ps corrosion in Postgate "B" medium with and without SRB culture are demonstrated in Table 2.

Triazoloazepinium bromides can be divided into two groups. The compounds of the first group (I-III, V, VIII, IX) turned out to be the inhibitors of microbial corrosion. However, their presence in the sterile medium accelerates the corrosion rate by up to 6,7 times. The inhibition efficiency varies, ranging from $94.4 \%$ for the compound $\boldsymbol{I}$ to $50.5 \%$ for the compound $\boldsymbol{I}$. At the same time, the correlation between the protective activity of triazoloazepinium bromides and their biocidal properties is not observed. Compound II demonstrates the highest protective activity, although it differs insignificantly from other studied compounds in biocidal properties. The most effective biocide (compound $\boldsymbol{I}$ ) inhibits steel biocorrosion only by $50.5 \%$. 
Table 2. Triazoloazepinium bromides (1 g/l) effect on steel St3ps corrosion (exposure time -75 days)

\begin{tabular}{|c|c|c|c|c|c|c|}
\hline \multirow{2}{*}{ 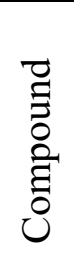 } & $\begin{array}{l}\mathrm{k}_{\mathrm{m}} \cdot 10^{3}, \\
\mathrm{~g} /\left(\mathrm{m}^{2} \cdot \mathrm{h}\right)\end{array}$ & $\gamma_{\mathrm{m}}$ & IE, \% & $\begin{array}{l}\mathrm{k}_{\mathrm{m}} \cdot 10^{3}, \\
\mathrm{~g} /\left(\mathrm{m}^{2} \cdot \mathrm{h}\right)\end{array}$ & $\gamma_{\mathrm{m}}$ & IE, \% \\
\hline & \multicolumn{3}{|c|}{$\begin{array}{c}\text { Postgate "B" } \\
\text { medium with SRB }\end{array}$} & \multicolumn{3}{|c|}{$\begin{array}{l}\text { Postgate "B" } \\
\text { medium }\end{array}$} \\
\hline- & 4.45 & - & - & 2.42 & - & - \\
\hline$I$ & 2.20 & 2.02 & 50.5 & 5.11 & 0.47 & - \\
\hline II & 0.25 & 17.80 & 94.4 & 14.23 & 0.17 & - \\
\hline III & 2.01 & 2.21 & 54.8 & 16.06 & 0.15 & - \\
\hline$I V$ & 26.60 & 0.17 & - & 1.70 & 1.42 & 29.6 \\
\hline$V$ & 1.73 & 2.57 & 61.1 & 5.56 & 0.44 & - \\
\hline$V I$ & 28.70 & 0.16 & - & 1.45 & 1.67 & 40.1 \\
\hline VII & 25.10 & 0.18 & - & 23.73 & 0.11 & - \\
\hline VIII & 1.20 & 3.71 & 73.1 & 8.26 & 0.29 & - \\
\hline$I X$ & 1.10 & 4.05 & 75.3 & 2.43 & 1.00 & - \\
\hline$X$ & 21.19 & 0.21 & - & 8.74 & 0.28 & - \\
\hline
\end{tabular}

The compounds of the second group (IV, VI, VII, X), despite their high biocidal activity, accelerate steel biocorrosion by 4.76-6.25 times. Correspondingly, they either have no effect (accelerate corrosion by 4.8-6.25 times), or little effect in the medium free of bacteria.

\section{Electrochemical measurements}

The effect of the studied compounds on the electrochemical part of the corrosion process was evaluated with the polarization measurement. Figure 2 shows the polarization curves for mild steel in Postgate "B" medium with SRB culture at the presence and absence of triazoloazepinium bromides.
The dependence of the current density on the electrode potentials indicates the presence of fairly complicated multistage processes under the conditions of cathodic and anodic polarization of steel in water-salt Postgate "B" medium with SRB culture (Fig. 2).

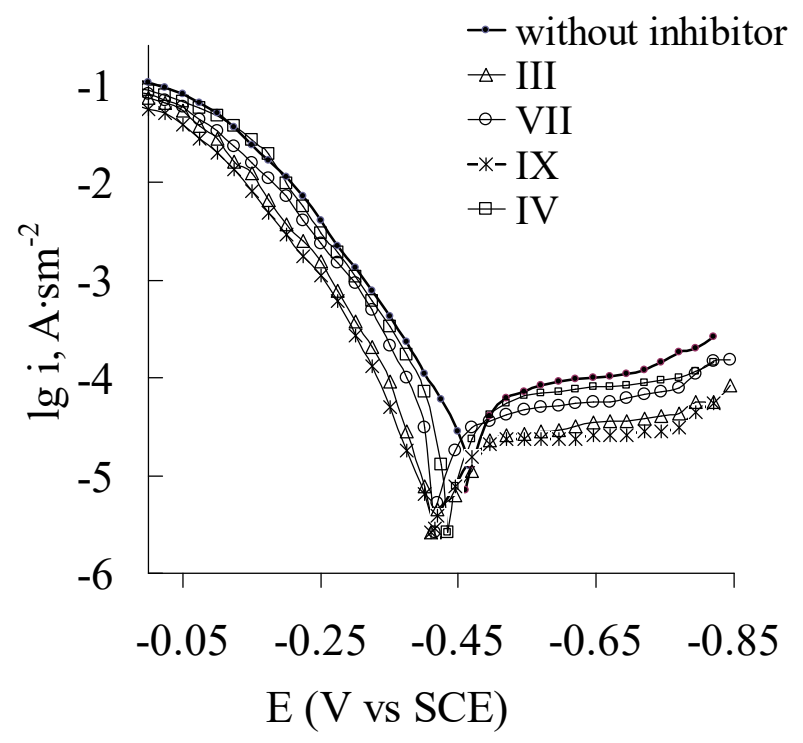

Figure 2. Polarization curves for St3ps steel in water-salt Postgate "B" medium with SRB culture at the presence and absence of triazoloazepinium bromides $(0,5 \mathrm{~g} / \mathrm{l})$.

The speed rate of the cathodic hydrogen evolution is much higher that the speed rate of the anodic Fe dissolution either at the presence and absence of triazoloazepinium bromides. Both the cathodic slopes and the anodic slopes do not change obviously, which indicates that the mechanism of the corrosion reaction under the conditions does not change. The bigger effect is observed for the compounds $\boldsymbol{I I I}$ and $\boldsymbol{I} \boldsymbol{X}$, which turned out to be biocorrosion inhibitors (Table 2). The corrosion reaction is inhibited by a simple adsorption mode. In the other words, the compound decreases the surface area for 
corrosion without affecting the mechanism of corrosion and only causes inactivation of a part of the metal surface.

It is observed, that the addition of triazoloazepinium bromides to solution greater reduces the corrosion rates of both the cathodic hydrogen evolution and the anodic $\mathrm{Fe}$ dissolution. Thus, these compounds can be treated as mixed-type inhibitors with predominant cathodic effect. The corrosion potential ( $\left.E_{\text {corr }}\right)$ obviously changes. As a result of adding triazoloazepinium bromides to solution, potential shifts to the positive side on 25-50 mV.

The peculiarity of the electrochemical activity of compounds $\boldsymbol{I V}$ and $\boldsymbol{V I I}$ is that, having the potential close to the value of steel corrosion potential $\left(\mathrm{E}_{\mathrm{corr}}\right)$ in water-salt Postgate "B" medium without SRB culture, they accelerate the anodic process.

\section{Quantum chemical calculations}

Triazoloazepinium bromides are characterized (Table 3) by high electronegativity $(\chi)$ and act as strong $(\Delta \mathrm{E}>1$ $\mathrm{eV}$ ) electrophiles $(\mathrm{A}>0)$. No correlation between quantum chemical properties (the orbital energies $\mathrm{E}_{\text {HOMO, }} \mathrm{E}_{L U M O}$ and value of HOMO-LUMO gap $(\Delta \mathrm{E})$, which characterizes chemical activity of molecules) and the ability to inhibit steel biocorrosion is observed.

This is due to the specific conditions of the action of molecules with biocidal properties in microbial corrosion. The presence of an equally charged surface of the metal and the surface of the bacterial cell creates conditions for competing adsorption. In this case, the distribution of charges on adsorption-reaction centers is important.

Table 3. Calculated quantum chemical properties of triazoloazepinium bromides

\begin{tabular}{|c|c|c|c|c|c|c|c|}
\hline 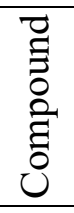 & I & A & $\begin{array}{c}\chi \\
\mathrm{eV}\end{array}$ & $\begin{array}{c}\eta \\
\mathrm{eV}\end{array}$ & $\mathrm{S}$ & $\begin{array}{l}\Delta \mathrm{E} \\
\mathrm{eV}\end{array}$ & $\begin{array}{l}\omega, \\
\mathrm{eV}\end{array}$ \\
\hline$I$ & 11.461 & 4.707 & 8.084 & 3.377 & 0.148 & 6.754 & 2.021 \\
\hline$I I$ & 9.551 & 4.099 & 6.825 & 2.726 & 0.183 & 5.452 & 1.706 \\
\hline III & 9.504 & 4.087 & 6.795 & 2.709 & 0.185 & 5.417 & 1.699 \\
\hline$I V$ & 9.521 & 4.096 & 6.809 & 2.713 & 0.184 & 5.425 & 1.702 \\
\hline$V$ & 9.659 & 3.600 & 6.630 & 3.030 & 0.165 & 6.059 & 1.657 \\
\hline$V I$ & 9.858 & 4.181 & 7.012 & 2.839 & 0.176 & 5.677 & 1.755 \\
\hline VII & 11.207 & 4.862 & 8.035 & 3.177 & 0.158 & 6.345 & 2.009 \\
\hline VIII & 9.652 & 3.725 & 6.689 & 2.964 & 0.169 & 5.927 & 1.672 \\
\hline$I X$ & 11.679 & 4.875 & 8.286 & 3.402 & 0.147 & 6.804 & 2.069 \\
\hline$X$ & 9.578 & 4.072 & 6.825 & 2.753 & 0.182 & 5.506 & 1.706 \\
\hline
\end{tabular}

Different effect of triazoloazepinium bromides on steel biocorrosion rate can be explained by the molecular structure, particularly the distribution of the effective charges on adsorption-reaction centres (Table 4). The substances, which demonstrated inhibitive performance under biocorrosion (I-III, V, VIII, $\boldsymbol{I X}$ ), have electron donor substitutes in the molecule aniline fragment, which causes the increase of electronic density on the Carbon atoms of benzene nucleus. Nitrogen atom of the 
amide group $\left({ }^{1} \mathrm{~N}\right)$ and Carbon atom $\left({ }^{2} \mathrm{C}\right)$ from the adjoining methylene group become positively charged.

Table 4. Distribution of the charges on the main adsorption-reaction centres of triazoloazepinium bromides molecules

\begin{tabular}{|c|c|c|c|c|c|c|}
\hline \multirow{2}{*}{ 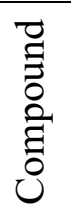 } & \multicolumn{6}{|c|}{$\begin{array}{c}\text { Numbers of atoms - the main adsorption- } \\
\text { reaction centres }\end{array}$} \\
\hline & ${ }^{1} \mathrm{~N}$ & ${ }^{2} \mathrm{C}$ & ${ }^{3} \mathrm{~N}$ & ${ }^{4} \mathrm{~N}$ & ${ }^{5} \mathrm{~N}$ & ${ }^{6} \mathrm{O}$ \\
\hline
\end{tabular}

Group of compounds, inhibiting microbial corrosion

\begin{tabular}{|c|c|c|c|c|c|c|}
\hline $\boldsymbol{I}$ & 0.039 & 0.027 & 0.035 & 0.080 & -0.184 & -0.324 \\
\hline $\boldsymbol{I I}$ & 0.038 & 0.028 & 0.038 & 0.077 & -0.181 & -0.315 \\
\hline $\boldsymbol{I I I}$ & 0.272 & 0.173 & -0.329 & -0.203 & -0.162 & -0.239 \\
\hline $\boldsymbol{V}$ & 0.039 & 0.027 & 0.036 & -0.185 & 0.080 & -0.321 \\
\hline $\boldsymbol{V I I I}$ & 0.039 & 0.028 & 0.036 & -0.183 & 0.080 & -0.326 \\
\hline $\boldsymbol{I X}$ & 0.055 & 0.041 & 0.319 & -0.162 & 0.397 & -0.303 \\
\hline
\end{tabular}

Group of compounds, accelerating microbial corrosion

\begin{tabular}{|c|c|c|c|c|c|c|}
\hline $\boldsymbol{I V}$ & 0.050 & -0.051 & 0.158 & -0.080 & 0.245 & -0.314 \\
\hline $\boldsymbol{V I}$ & 0.102 & -0.043 & 0.158 & -0.071 & 0.204 & -0.320 \\
\hline $\boldsymbol{V I I}$ & 0.086 & -0.044 & 0.138 & -0.072 & 0.219 & -0.325 \\
\hline $\boldsymbol{X}$ & -0.003 & -0.041 & 0.188 & -0.100 & 0.285 & -0.303 \\
\hline
\end{tabular}

This facilitates quick electrostatic interaction of the molecule, particularly with amide Nitrogen, with the negatively charged steel surface under the competing adsorption (the bacteria cell surface also has negative charge within the range from -8 to $-36 \mathrm{mV}$ [24]). The inhibitor molecules are able to be absorbed on the steel surface before it is colonized by the microorganisms. Presently, inhibitor molecules with negatively charged adsorption-reaction centres (Nitrogen atoms of triazol cycle, Oxygen, benzene rings) slowly interact with the unfinished $d$-sublevels of $\mathrm{Fe}$ atom, resulting in the creation of bonds by transferring electrons to metal. This is proven with the data of the X-ray diffraction, which indicate the presence of Nitrogen (constituting the inhibitors), in the steel surface layers (Fig. 3).

\section{Surface Morphology Studies}

In order to further discuss whether the substitution of electron-substituents in aniline fragment of the molecule is the main reason for the efficient inhibitive performance, additional experiment of EDS analysis of corrosion products was carried out. EDS was taken to verify the mechanism of corrosion products, formed on the metal surface. Fig. 3 and Fig. 6 shows the corresponding EDS analysis of corrosion products before and after the scouring experiment in different systems. The EDS results (Fig. 3 a) suggest that the main corrosion products are evidently iron oxides and iron sulfide on SRB coupons. The mole fraction of $\mathrm{O}, \mathrm{S}$ and Fe remains approximately equal before and after the experiment, suggesting that the scouring experiment has no influence on SRB coupons. The EDS analysis results (Fig. 3 a) indicate the predominant presence of $\mathrm{Fe}$ and $\mathrm{O}$ in corrosion products on coupons. The molar ratio of $\mathrm{Fe}$ to $\mathrm{O}$ is about 7:10, indicating that the main corrosion products can be either $\mathrm{Fe}_{2} \mathrm{O}_{3}$ or 
$\mathrm{Fe}_{3} \mathrm{O}_{4}$, or other iron oxides. The mole fraction of $\mathrm{O}$ and $\mathrm{Fe}$ remains unchanged after the experiment, suggesting that the triazoloazepinium bromides are present on the metal surface on coupons. And the molar ratio of $\mathrm{Fe}$ to $\mathrm{O}$ is about 3:5, suggesting that the main corrosion products can be either $\mathrm{Fe}_{3} \mathrm{O}_{4}$ or other iron oxides.

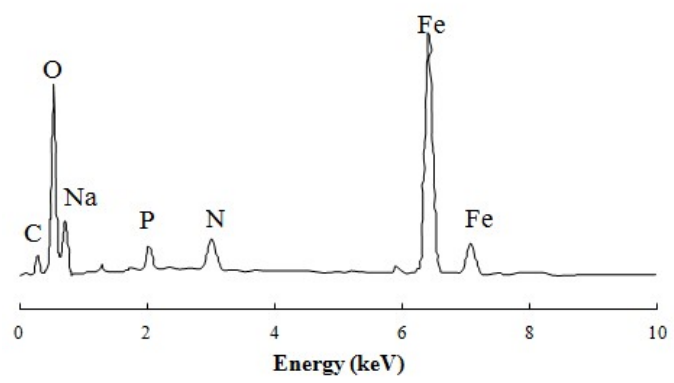

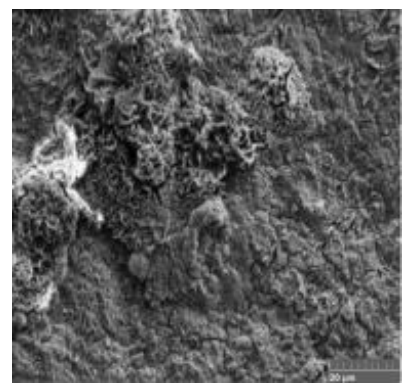

$\mathrm{a}$

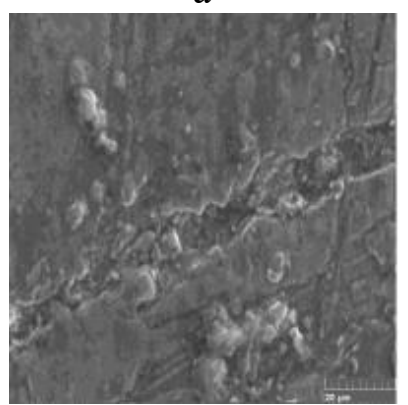

c

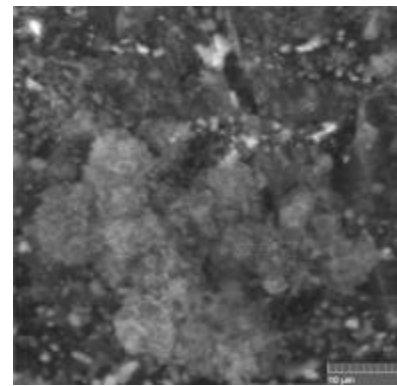

b

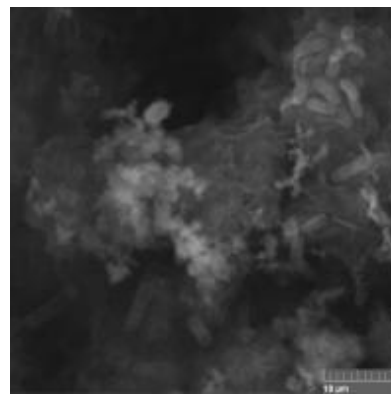

d

Figure 4. FE-SEM images for the biofilm developed on St3ps steel surface after exposure to Postgate "B" medium with SRB culture with inhibitors: a) $\times 1000$; compound III; b) $\times 8000$ compound $\boldsymbol{I I I} ; c) \times 1000$; compound $\boldsymbol{I} \boldsymbol{X}$; d) $\times 8000$ compound $\boldsymbol{I} \boldsymbol{X}$.

The compounds, which accelerate steel biocorrosion rate $(\boldsymbol{I V}, \boldsymbol{V I}, \boldsymbol{V I I}, \boldsymbol{X})$, have one or several $\mathrm{Cl}$-substitutes in the benzene nucleus, bonded with amide Nitrogen. Considerable inductive $-I$-effect with little conjugation effect $(+M$-effect), characteristic for electron acceptor Chlorine atom, causes the decrease of electron density on Carbon atoms of benzene ring of aniline fragment. At the same time, Nitrogen $\boldsymbol{I I I}, \boldsymbol{V}, \boldsymbol{V I I I}$ and $\boldsymbol{I X}$ in the corrosive medium, a biofilm is formed on the protective layer of the inhibitor (Fig.4). Such biofilm is not corrosively active. This is correspondent to [25], that the adsorption of an organic inhibitor is an obligatory condition of inhibitive performance under biocorrosion. and Carbon atom of conjugated methylene group - a negative one. This complicates the electrostatic interaction of the molecule with the metal surface, so that microorganisms have time to colonize it and form a biofilm (Fig.5). 


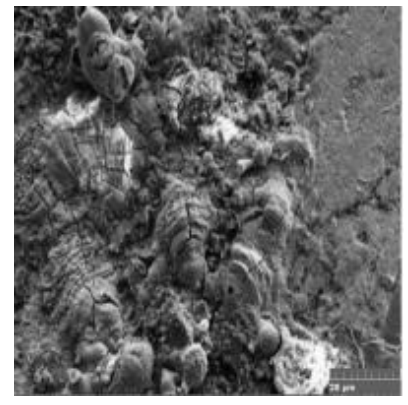

a

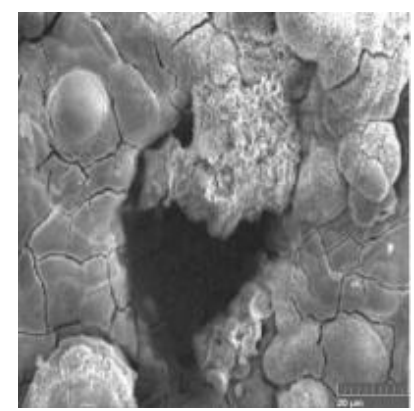

$\mathrm{c}$

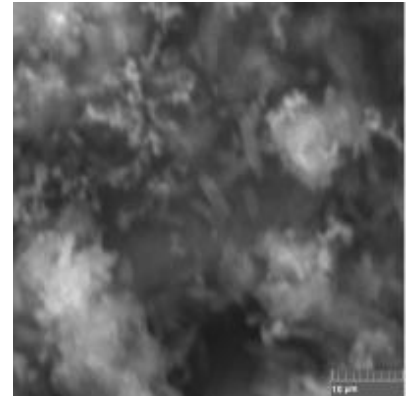

$\mathrm{b}$

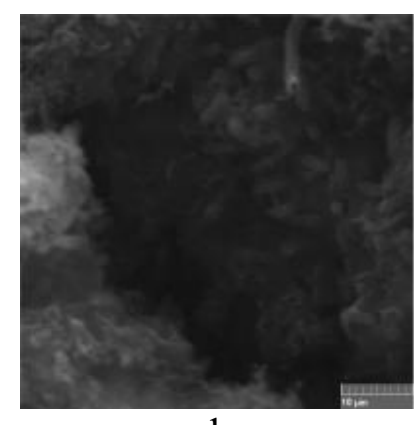

d
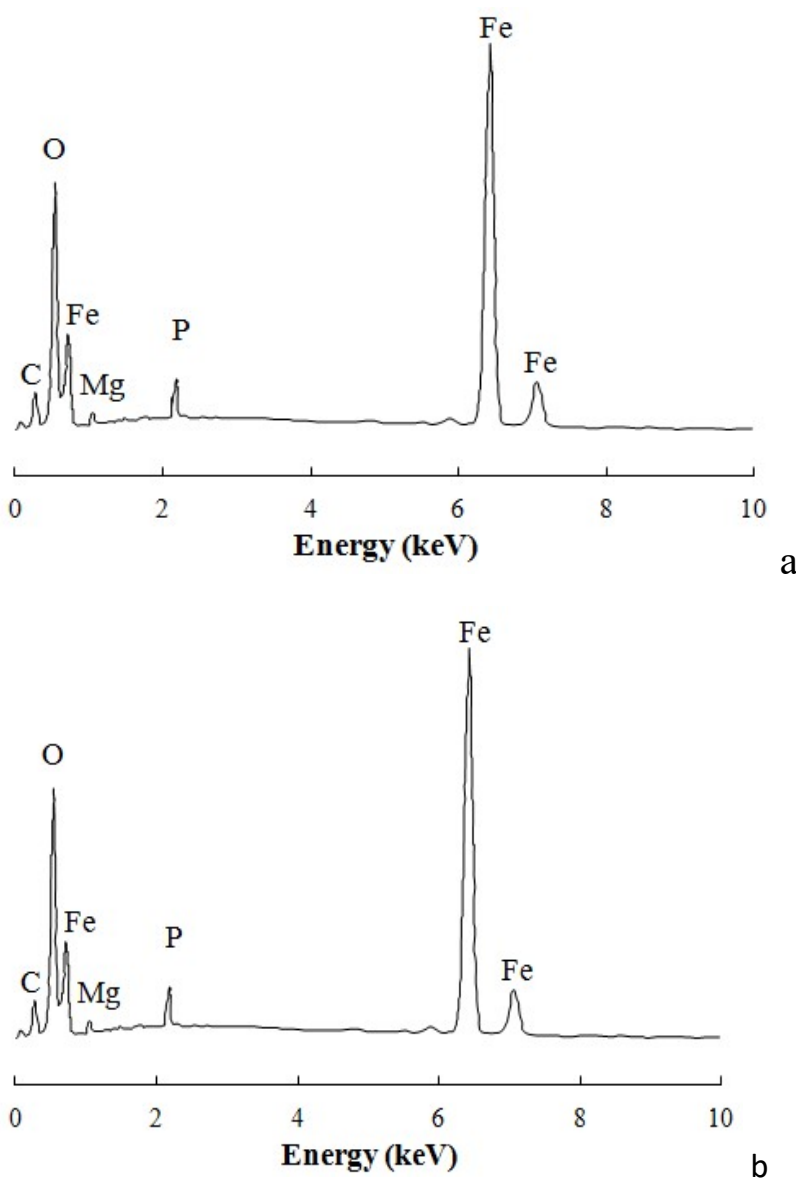

Figure 6. Elemental composition of steel surface layers under the exposure in the Postgate "B" medium with SRB culture and compound: a) $\boldsymbol{I V}$ and b) $\boldsymbol{V I I}$.

With the increase of steel St3ps coupons exposure time in the corrosive medium the protective activity of the triazoloazepinium bromides with the properties of biocorrosion inhibitors retains. At the same time, the inhibition efficiency turned out to be higher (Table 5), compared to the results after 75 days exposure (Table 2). For the compounds I-III and $\quad \boldsymbol{I} \boldsymbol{X}$ it equals $97.1 \%-98.7 \%$. The concentration of hydrogen sulfide (the main product of SRB metabolism) in the corrosive medium appeared to be less by $52.5 \%-78.8 \%$ 
due to the decrease in number and inhibition of microorganisms' activity.

Table 5. Triazoloazepinium bromides effect

(1 g/l) on steel St3ps biocorrosion (exposure time - 180 days)

\begin{tabular}{|c|c|c|c|}
\hline 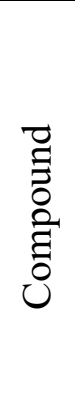 & $\mathrm{IE}, \%$ & $\begin{array}{l}\text { Decrease in SRB } \\
\text { number in the } \\
\text { corrosive medium, } \\
\text { (orders) } \\
\text { coupons exposure } \\
\text { time }\end{array}$ & $\begin{array}{c}C \\
\left(\mathrm{H}_{2} \mathrm{~S}\right), \\
\% \text { of } \\
\text { control }\end{array}$ \\
\hline$I$ & 98.0 & 6 & 21.2 \\
\hline II & 98.7 & 5 & 47.5 \\
\hline III & 98.1 & 5 & 26.5 \\
\hline$I X$ & 97.1 & 5 & 34.4 \\
\hline
\end{tabular}

The effect of concentration on inhibition efficiency was defined for compound II (Table 6). It was established that even under the concentration $0.1 \mathrm{~g} / 1$, the inhibition efficiency is sufficiently high.

Table 6. Effect of compound II concentration on inhibition efficiency of steel St3ps biocorrosion (exposure time -7 days)

\begin{tabular}{|l|l|l|l|l|}
\hline Concentration, g/1 & 0.1 & 0.25 & 0.5 & 1.0 \\
\hline IE, \% & 72.2 & 75.6 & 79.6 & 85.9 \\
\hline
\end{tabular}

\section{Conclusions}

Triazoloazepinium bromides with biocidal activity against sulfate-reducing bacteria of Desulfovibrio sp. M.4.1 strain are represented by the compounds, decelerating microbial corrosion, and compounds, accelerating it.

The determining factor of triazoloazepinium bromides inhibitive performance is the specific distribution of the charges on the adsorption-reaction centres, which under conditions of competing adsorption allows them to form a protective film before corrosively active microorganisms settle on the metal surface.

Biofilm, formed on the protective film layer of the biocidal inhibitor, is not corrosively aggressive, ensuring long-term protection up to $98.7 \%$ of steel St3ps against biocorrosion.

\section{References}

[1] Ryazanov AV, Vygdorovych VI, Zavershynskyi AN. Biokorrozija metallov. Teoreticheskie predstavlenija, metody podavlenij. Vestnik TGU, 2003;8(5) 821-837.

[2] Kozlova IP, Radchenko OS, Stepura LGh, Kondratjuk TO, Piljashenko-Novokhatnyj AI. Gheokhimichna dijaljnistj mikroorghanizmiv ta jiji prykladni aspekty. Kyjiv: Naukova dumka; 2008: pp $297-$ 300 .

[3] Teryusheva SA, Beloglazov GS, Beloglazov SM. Proizvodnyie 1,4-gidrohinona V roli ingibitorov korrozii i navodorazhivaniya stali v prisutstvii SVB. Vestnik Samarskogo gosudarstvennogo universiteta 2011;86(5):136-143.

[4] Teryusheva SA, Beloglazov SM. Ingibitoryibiotsidyi dlya zaschityi stali ot korrozii v vodno-solevoy srede s SRB. Izvestiya KGTU 2007;11:262-267.

[5] Veliev MG, Chalabieva AZ, Vezirova IA et al. Funktsionalnyie proizvodnyie atsetilena kak reagentyi dlya podavleniya rosta sulfatvosstanavlivayuschih 
bakteriy pri neftedobyiche. Neftehimiya. 2010;50(6):492496.

[6] Sheng XX, Ting YP, Pehkonen SO. Inhibition of Microbiologically Influenced Corrosion of Mild Steel and Stainless Steel 316 by an Organic Inhibitor. Adv Mat Res. 2007;20-21:379-382.

[7] Sheng XX, Ting YP, Pehkonen SO. Evaluation of an Organic Corrosion Inhibitor on Abiotic Corrosion and Microbiologically Influenced Corrosion of Mild Steel. Ind. Eng. Chem. Res. 2007;46(22):7117 7125 .

[8] Kurmakova I, Prihodko S, Demchenko N., Bondar E, Gumenyuk O, Tretyak A. Protivokorrozionnye svojstva soedinenij s zameshchennym triazoloazepinievym ciklom kak ehffekt sinergizma. Specvipusk Fiziko-himichna mekhanika materialiv. 2010;5:454-459.

[9] Bondar ES, Kurmakova IN, Demchenko NR, Sizaya OI. Mnogofunkcional'nye ingibitory korrozii uglerodistoj stali na osnove bromidov imidazoazepiniya. Korroziya: materialy, zashchita. 2013;12:25-30.

[10] Smykun NV, Tretyak AP, Kurmakova IN. Kineticheskaya harakteristika biocidnogo dejstviya proizvodnyh N-izopropil-N-fenil-2-hloracetamida. Visnyk Odesjkogho nacionaljnogho universytetu. Serija Biologhija. 2001; 6(4):285-289.

[11] Bondar OS, Prykhod'ko SV, Kurmakova IM, Humeny OL. Inhibiting action of nitrogen-containing heterocycles in corrosion of low-carbon steel. Materials Science. 2011;47(3):370-374. doi: 10.1007/s11003-0119405-6

[12] Kurmakova I, Bondar O, Polevichenko S, Demchenko N. Quaternary Pyridinium Salts As Inhibitors Of Mild Steel Biocorrosion. Chem. Chem. Technol. 2017;11(3):314-318. doi:10.23939/chcht11.03.314

[13] Demchenko NR, Kurmakova IM, Tretjak OP. Biocydna dija chetvertynnykh tryazoloazepinijevykh solej na korozijno nebezpechni mikrobni ughrupovannja. Naukovyj visnyk
Uzhghorodsjkogho universytetu. Serija: biologhija. 2007; 20:18-21.

[14] Demchenko NR, Kurmakova IM, Tretjak OP. Metabolichna ta korozijna aktyvnistj suljfatvidnovljuvaljnykh bakterij za prysutnosti chetvertynnyj solej tryazoloazepiniju. Visnyk Zaporizjkogho universytetu. 2008; 2:41-46.

[15] Kurmakova IM, Bondar OS, Demchenko NR. Quantum-Chemical Characteristics as a Criterion of Efficiency of Quaternary Salts with Antibacterial Properties for the Inhibition of Biocorrosion of Steel. $\begin{array}{lllll}\text { Materials } & \text { Science. } & 2016 & 51 & \text { (5):610-617. }\end{array}$ doi:10.1007/s11003-016-9882-8.

[16] Demchenko NR, Prykhodjko SV, Kurmakova IM. Antymikrobni vlastyvosti bromidiv imidazoazepiniju. Paper presented at: UCOC 2010. Abstracts of XXIV Ukrainian Conference of Organic chemistry, 2010 Sep 20-25; Uzhghorod, Ukraine 2010, p. 337 .

[17] Ismail M., Yahaya N., Bakar AA, Noor NM. Cultivation Of Sulphate Reducing Bacteria In Different Media. Malaysian Journal of Civil Engineering. 2014.;26(3):456-465.

[18] Demchenko NR, Kurmakova IM, Tretjak OP. Osoblyvosti korozijnoaktyvnogho mikrobnogho ughrupovannja ferosfery ghazoprovodu, prokladenogho $\mathrm{u}$ pishhanomu grunti. Mikrobiologhija i biotekhnologhija. 2013;4:90-98.

[19] Fokin MN, Zhigalova KA. Metody korrozionnyh ispytanij metallov . Moskow: Metallurgija; 1986, pp. 11-18.

[20] Xua C, Zhanga Y, Chenga B, Zhub W. Pitting corrosion behavior of 3161 stainless steel in the media of sulphate-reducing and iron-oxidizing bacteria. Materials Characterization. 2008;59(3):245-255. doi:10.1016/j.matchar.2007.01.001

[21] Chermette H. Chemical reactivity indexes in density functional theory. J. Comp. Chem. 1999;20:129154. 
[22] Gece G. The use of semiempirical calculations in corrosion inhibitor studies. Journal of corrosion. 2007;15(1-2):12-21.

[23] Pearson RG. Absolute electronegativity and hardness correlated with molecular orbital theory. Proc Natl Acad Sci USA. 1986;83:8440-8441.

[24] Kurdysh YK. Zakonomernosty vzaymodejstvyja mykroorghanyzmov s tverdymy materyalamy. Mikrobiologhichnyj zhurnal. 2001;63(6):71-88.

[25]. Beloglazov GS, Beloglazov SM. Zashchita ot korrozii i navodorozhivaniya stali organicheskimi ingibitorami: eksperimental'nyye i kvantovo-khimicheskiye issledovaniya. Vestnik Baltiyskogo federal'nogo universiteta im. I. Kanta. 2013;1:30-38. 